\title{
Between a rock and a hard place: dilemmas regarding the purpose of public universities in South Africa
}

\author{
Rebecca Swartz ${ }^{1}$ (D) Mariya Ivancheva ${ }^{2}$. \\ Laura Czerniewicz ${ }^{1}$ - Neil P. Morris ${ }^{2}$
}

C) The Author(s) 2018, corrrected publication 2018

\begin{abstract}
This paper examines the idea of 'core business' in contemporary South African public universities. South Africa's public higher education system has global ambitions, but is also highly internally stratified. Drawing on new data from interviews with higher education leaders and government policymakers across a number of South African institutions, we show that while the rhetoric of 'core business' of the university has been adopted by higher education leaders, the question of what constitutes the purpose of the university, in South Africa and arguably beyond, is subject to ongoing debate and negotiation. The multiplicity of conflicting but coexisting narratives about what universities should do in South African society_-producing excellent research, preparing a labour force, or addressing societal inequalities - exposes a persisting tension surrounding the purpose of a public university. And while this tension has historical origins, we show that responses to addressing these various roles of the institution are not developed organically and in a neutral context. They emerge under conflicts over limited state funding and attendant and opportune market pressure put on public universities in times of crisis, that shape profoundly their framing and outcomes, and the future of the universities.
\end{abstract}

Keywords South Africa $\cdot$ Core business $\cdot$ Public universities $\cdot$ Purpose of higher education

Rebecca Swartz

Rebecca.swartz@uct.ac.za

1 Centre for Innovation in Learning and Teaching, University of Cape Town, Rondebosch,

Cape Town 7700, South Africa

2 School of Education, University of Leeds, Leeds, UK 


\section{Introduction}

Over the past two decades, the purpose of universities has been under close scrutiny. Their very existence is being widely interrogated as they are referred to as being in a state of crisis (Readings 1999; Washburn 2008). The pressures both upon and within universities have led to serious reflection about the very nature of these institutions (Collini 2017; Marginson 2016a, b; Holmwood 2014 and others) and what should constitute their 'core business'. This issue emerged as a dominant consideration in a research project examining the changing nature of higher education in South Africa and England. The project examines the unbundled university - the intersection of increasingly disaggregated curricula and services, the use of digital technologies, the growing marketisation of higher education itself, and the deep inequalities which characterise the sector and the contexts in which they are located. At the heart of this intersection lies the matter of the primary and overriding purpose of the public university. This is the focus of this paper.

The concept of 'core business' explored in this paper is a phrase notably used by interviewees in our project when discussing the purpose of universities. The paper reports on interviews with over 30 university leaders, both academic and managerial, government and parastatal officials in South African higher education. The notion of 'core business' itself has a history in corporate governance (Wysocki 1999) and has subsequently been applied to higher education. The phrase implies that there should be a single, identifiable, 'core business' of a university, eliding the multiple functions that a university might serve, and the many forms of relationships that constitute an institution (including between staff and management, staff and students, research and teaching, and so on). The very question of a 'core business' of a 'public university' is problematic: it either expresses an oxymoron in that public institutions have not traditionally been associated with business practices, or reveals a new frontier of the interface of public and private at state-subsidised universities. Yet, while much has been written about the commercialisation, corporatisation, commodification, privatisation, and marketisation of the public university as a sad matter of fact (Giroux 2014; Slaughter and Leslie 1997; Marginson 2016a, b; Shore and Wright 2016), our data reveal the ongoing tension these processes introduce into public universities. In South Africa, public universities are internally striving to achieve multiple, sometimes competing, imperatives, while externally presenting a unified and coherent message about what the public university's 'core business' entails.

South African universities are a potent ground for such exploration as they grapple with deep local imperatives refracted through powerful global discourses about the changing nature of higher education. While the country is ranked as one of the most unequal societies in the world (World Bank 2018), it is striving to secure a place as a hub of academic excellence. Higher education is, as in the case of many developed nations, predominantly publically funded and since the end of apartheid (the system of racial segregation initiated by imperial powers and inscribed in law by the nationalist government between 1948 and 1994) has been framed as equitable and attempting to redress inequalities. Social justice is a core concern in higher education in South Africa, and that requires redistribution towards parts of the country and social groups that remain economically marginal, and marginalised in terms of access to education. The competing demands on universities to provide a quality education that would be competitive if not only nationally and on the African continent, but also globally, continue to run up against the need for social redress in terms of policies of access and inclusion in the post-apartheid era (Bertelsen 1998: p. 138). At the same time, changes in higher education provision, policy, and practice in South Africa 'need to be understood in terms of marketisation 
and quasi-marketisation... and tempered by imperatives of redress and equity' (Ntshoe 2004: p. 137).

While we recognise the unique historical trajectories of higher education in South Africa, it is also essential to acknowledge the ways in which global changes in higher education impact on that context. Over the last decades, scholars have discussed a significant shift in the public/ private divide that has occurred with the advent of neoliberal governance and new public management on the turf of public universities first in the developed world and then worldwide (Ball 2009; Lynch 2014). This has happened through multiple reforms: the introduction of corporate funding, insistence that research and teaching occur at the industry/academia interface (Howells et al. 2012), the focus on employability as a key lens to understand higher education (Boden and Nedeva 2010), the concentration on hard sciences, infrastructural innovation and outsourcing of labour present on campuses (Lynch and Ivancheva 2015), and diversification of actors involved in higher education delivery (Komljenovic and Robertson 2016). This has also come with the standardisation and homogenisation of quality criteria through global and national rankings and the dominance of the Anglo-American research university model, increasingly adopted as an aspiration around the world (Marginson 2008).

There are also political, social, and economic processes which enable the marketisation of the public university. These can be used to explain the dichotomy between public and private in the university sector that can be seen as false in two ways. Firstly, Simon Marginson has shown that contradicting distinctions are made in distinguishing between public-private in relation to knowledge production. He argues the phrasing in economic terms, i.e. as nonmarket and market, or in political terms, i.e. as state-controlled and non-state controlled, is false dichotomies (Marginson 2016a, b). Secondly, the idea that states regulate against market interests has been challenged by numerous scholars, notably in the tradition of Karl Polanyi, who claimed that 'laissez-faire economy was the product of deliberate state action' (Polanyi 2001: p. 147). This view of the state requires an examination of the processes at stake which, as Robertson insists (following Jessop's strategic relational approach), looks 'into the contingent and tendential nature of structural constraints' ... and 'the cultural dimension of social life' that produce strategic structural selectivities and privilege certain actors and identities over others (Jessop 2005: p. 48; Robertson 2010: p. 192).

In light of these considerations, this paper reflects on whether there is a consensus around what forms the primary purpose of the public university in South Africa, or, if productive contradictions exist which provide an alternative approach to inform a rich dialogue and nuanced policy in this terrain. We first give a historical background to university education in South Africa, providing context to the current situation. We then move on to a discussion of understandings of the role of public universities as perceived by our informants, examining three competing demands on universities. Firstly, we discuss the financial imperatives of the university in the face of financial pressures; secondly, we examine the universities' need to maintain or enhance status through global ranking systems and promoting the university brand; and finally, we turn to the issue of social justice imperatives and reparations. Threaded through each of these thematic sections is a focus on how these issues relate to teaching and research functions at the university. Our argument is that these imperatives are in conflict with each other, putting immense pressure on universities to perform multiple roles simultaneously. In practice, this leads to certain imperatives being privileged over others, depending on the institution under discussion. We show that while the meaning of 'core business' was understood differently by individual interviewees, the current financial constraints have made 
income generation a primary concern across the sector and, effectively, a core business of the otherwise not-for-profit public university.

\section{Historicising 'core business' and the purpose of the South African university}

It is worth considering the historical trajectory of universities to show how common understandings of the role of public universities have changed. Sam and van der Sijde (2014) discuss four university historical models: the research-oriented Humboldtian model, the trainingoriented Napoleonic model, and the personality-oriented Anglo-Saxon model, which focuses on individual development rather than research and teaching. Today, the dominant 'hybrid' Anglo-American model combines some of the features of the older models. While focusing on research and technical training, it puts them to service in a highly competitive system in which governance is decentralised, and the participation of industry as employer is dependent on the individual skills and entrepreneurial ethos of students and the ability of the universities to fit the demands of a growing market (Sam and van der Sijde 2014: 896). This model has become globally accepted and has been adapted throughout the world, with some exceptions (Marginson 2008). The adoption of this model has been accelerated by the advent of the new decentralised governance paradigm of new public management, which has positioned institutional competition, audit, and performance management as central to higher education (see e.g. Lynch 2010; Bradmore and Smyrnios 2009). It has also been impacted by the related introduction of global rankings of higher education (Lynch 2010; Ivancheva 2013).

Alongside the development of these university models, there have also been shifts towards the massification of higher education which gained traction after the Second World War, particularly in postcolonial states (see e.g. Ordorika Sacristán 2003; Odhiambo 2014). This development has emphasised social justice and redistribution and widening participation through admitting new types of students including women, minorities, part-time and intermittent learners, and mature students (Gumport et al. 1997: p. 2).

These trends have played out with further complexity in the South African higher education system. South African universities, like those elsewhere, are facing pressures to widen access through making education more affordable to the majority of local students. At the same time, the university system is attempting to overcome and address systemic inequalities. During apartheid, a racially stratified system, enforced by the Extension of University Education Act (1959), provided education at research universities and technical institutions ('technikons') in South Africa. There were different institutions for white and black South Africans, and better resourced institutions generally catered to white populations. In the 1990s, the newly elected democratic government sought to redress inequalities in the public higher education system. At the same time, the African National Congress (ANC) government's commitment to a set of neoliberal economic policies from 1994 did not meet with success and the imagined economic growth for the country did not come to fruition (Marais 2001). In the case of higher education, 'Institutional change in post-1994 South African higher education has occurred in an epoch of globalization and in a conjuncture of the dominance of the ideology of neoliberalism' (Badat 2015: p. 79). This was expressed by the economic programme for Growth, Employment and Redistribution from 1996. This national economic plan positioned educational progress as 'a key determinant of long-run economic performance and income redistribution' (Treasury of South Africa 1996: p. 15) but also insisted on containing expenditure and reducing subsidies of 
education that amounted to 7\% of GDP spent per year (Treasury of South Africa 1996: p. 15). It suggested that an increased reliance on private involvement in higher education would help to enhance 'the educational opportunities of historically disadvantaged communities' (Treasury of South Africa 1996: p. 15). The 1997 White Paper on Higher Education made clear the role of universities in South Africa: their responsibilities included 'intellectual development' to address social inequalities, 'to meet the development needs of society' and prepare students for the labour market, to prepare socially aware and critical citizens, and to contribute to the production of knowledge. Thus, as in other cases globally (see Boden and Nedeva 2010), the education sector underwent cuts while put under an increased pressure to support the private sector and simultaneously address social problems.

Coupled with the new incentives for the massification of higher education, the market liberalisation policies in the early 1990s enabled a huge number of private providers to enter the higher education terrain. Initially encouraged by the government as potentially providing greater access to higher education (Bunting 2004: p. 103), the mushrooming of private higher education providers that attracted as many as 800,000 students was eventually regulated by the Department of Higher Education and Training. Their moratorium from 1998 warranted against private universities which were often not officially registered or accredited (Fehnel 2004: p. 237-238).

Regulation however worked only to put a stop on the proliferation of private providers. It did not deal with inequalities across the sector as a whole. While student numbers rose in historically advantaged institutions (HAIs) until 1997, the same did not occur in the historically disadvantaged institutions (HDIs) (Ntshoe 2004). Indeed, the historically black institutions 'felt the impact on enrolments more heavily than other institutions that were more highly regarded given historical status and resourcing' (Bozalek and Boughey 2012: p. 693). Regulatory restrictions were placed on the growth of satellite campuses, which could possibly challenge geographical inequalities (Ballim et al. 2016: p. 78). From 1998, enrolments declined across the sector as fewer matriculants than expected entered the system. In terms of funding, this meant that expected state subsidies to universities for first year enrolments did not come to fruition (Bunting 2004: p. 100). However, between 2007 and 2011, enrolment rates increased by $4.3 \%$ per year across the sector and $8.4 \%$ per year at the University of South Africa (UNISA), the large distance education provider in South Africa (Simkins et al. 2016: p. 342).

Between 2000 and 2013, the percentage of university income coming directly from government subsidy decreased from 49 to $40 \%$, sometimes falling even lower to $30 \%$ (Cloete 2016: p. 3). Third-stream income, i.e. income not drawn from government subsidies or student fees, while increasing in nominal terms, has remained constant in real terms over the same period (Cloete 2016: p. 3). While there have certainly been some major strides in massifying the higher education system, and particular universities have dramatically changed their demographic makeup, the system as a whole has been unable to cope with the lack of funding and pressures to widen access. To make up for the decreased government income and the lack of increased third-stream income, student fees have increased by $9 \%$ annually between 2010 and 2014 (Cloete 2016: p. 3), making higher education unaffordable to the general South African population. In response, the government has committed to providing more financial aid to students through the National Student Financial Aid Scheme (NSFAS). At the end of 2017, President Zuma announced that higher education would be free for poor and working-class students - those with a combined family income of less than R350 000 per year (about \$28,406 US) (Davis 2017). 
However, this remains insufficient to deal with the demand for higher education. Lack of finances coupled with an ailing basic education system means that higher education remains largely accessible to the elite, with most students currently achieving a university exemption being in the higher decile ranges in terms of family income (Van der Berg 2016). Inequalities have also persisted in the racial and class demographic makeup of universities: between 2009 and 2014, black participation in higher education grew from 13 to $15 \%$, while white participation decreased from 58 to 54\% (Council on Higher Education 2014: p. 5). White students still have higher success rates and are more likely to graduate within 3 years than their black peers. Indeed, $39 \%$ of white students who enrolled in 3-year undergraduate degree programmes in 2009 graduated in the minimum time, compared to $20 \%$ of black students. By the end of 6 years, $61 \%$ of white students who started in 2009 completed their 3 -year degrees, while only $51 \%$ of black students from the same cohort graduated (Council on Higher Education 2014: p. 63).

On an annual basis since 2015, many South African universities have shut down for days or weeks as students have protested against rising fees which have made higher education unattainable to the majority of South Africans, under the broad banner of the \#FeesMustFall protests. Student protests are not a new phenomenon: at HDIs, students have long protested the inequalities of the system, including the lack of adequate funding and resources (see Badat 2015). However, these protests occurred on elite university campuses for the first time since 1994, as the universities of Cape Town, Witwatersrand, and others shut down face-to-face teaching and learning activities for a period of time (see Langa 2017). At the heart of these protests have been conflicting narratives regarding the purpose of a public university in postapartheid South Africa, and different responses to the pressures facing universities. One narrative, largely student-driven, has seen a vision of universities as functioning as institutions that would serve, and be accessible, to the majority. As we show in this paper, another narrative, in an austerity economic climate, has seen university leaders subject to intense financial strain, with pressures to expand the 'business' of the university to find new ways of generating income. There have also been new pressures on universities to provide online or digital offerings, both as a means of generating income, and to enhance students' flexibility. With this context in mind, we now turn to our interviewee's perceptions of the 'core business' of public universities, focusing on the tensions surrounding their purpose in South Africa today.

This data is rare in the South African context for its inclusion of the views of senior leaders including vice-chancellors, government advisors, and some senior academic leaders such as deans (for another example, see Jansen 2017). We use data from interviews conducted at two elite, urban, HAIs (Universities A and S), one comprehensive university (University C), a distance education provider (University M), and one HDI (University B). The paper provides insight into how those in leadership positions are thinking about the purpose of public universities in South Africa today and how they are grappling with where institutional priorities should lie.

\section{Core business: focusing on finance, balancing the costs}

Although HAIs have fared better since 1994, due to their ability to gain alumnus donations and to attract large research grants from outside the government, they have also begun to feel the effects of reducing government subsidies (Badat 2015: p. 74). The focus on research as a way 
of enhancing the visibility of the university 'brand', through rising in global ranking systems, attracting research funding and international staff and students, has been both a strategy and a concern at some of South Africa's more elite universities. This emerged as a key concern of our interviewees at historically advantaged institutions. In the face of limited state funding for higher education, the growth of a research-intensive portfolio has been a way to generate 'third-stream' income in order to supplement the institution's income from student fees and government subsidies. Some of these universities are beginning to explore online education as a means to grow third-stream income, either working independently or in partnership with private companies. At historically disadvantaged institutions, the issue of generating thirdstream income was just as relevant, but there were fewer examples of partnerships that universities were hoping could bring in funding.

At University A, an elite HAI, the vice-chancellor pointed out that the context of limited state funding was having an impact on the university's ability to perform its traditional functions, which he saw as teaching and research:

In an ideal world, my preference would be that we would be a public university, onehundred-percent funded by the state and that we would not have to generate revenue for our main business; for our main business meaning teaching, and for the core of our research; and that the only revenue we would generate then would be research grants that we would write proposals for in competitive bids.

The vice-chancellor, a role he described as '[e]ffectively the CEO and, but also responsible for providing academic leadership in the university', positioned teaching and research as the 'main' business of the university. He noted, however, that lack of government funding was pushing universities into a space where it was increasingly likely that they would need to generate third-stream income in order to support their teaching and research activities. He spoke about the university's property holdings as a way to generate income and suggested that the university should do more to run 'income-generating courses', possibly in online modes, and recruit more international students who could pay higher fees.

[W]e have a strong brand and I anticipate that government funding is going to be in continual decline over the next five/ten years; the economy isn't good and either we have to say, we're willing to go down with that economy, two or three-percent a year and in ten years' time we'll be spending twenty-percent less and we'll have twenty-percent worse staff-student ratio, twenty-percent less time for research, I see a gradual twopercent decline in state funding every year and we can say we don't want to generate money from other sources and we'll just cut our, our suits, cut our cloth according to what we have.

In his view, raising additional income was not a choice but a necessity if the university was to continue to function at its current level, as a world-renowned top African university. 'I can't see any reason not to use what resources we have to generate as much money as we can to do the main business, as long as it's going to promote the main mission of the university.' The argument here was that teaching and research constituted the main business of the institution with the danger being that these could be neglected in the face of limited funding, especially where the need to compete for research and other forms of external funding might be prioritised in order to keep the university afloat. 
An academic leader at University $\mathrm{S}$ described the tension between the imperatives of balancing the teaching and research needs of the university with the need to save money in the context of austerity:

So you've got to be dealing with the intellectual work of a full faculty and a university and you know that [University $\mathrm{S}$ ] has positioned itself as a research intensive university. So that itself comes with several competing imperatives. There's this intellectual and academic leadership but coupled with that of balancing that with financial sustainability and human resources. Now the financial sustainability one can still work around because it is about driving up income and bringing down costs as much as possible.... [...] So I think this is a day to day tension that one's got to balance all the time and one's got to always foreground the intellectual project but with great difficulty because they are bigger and bigger demands now on the university to be more sustainable, to be an employer that is a fair...

This interviewee called into question the competing demands being made on the university. Echoing an interviewee from University A, she argued that financial pressures were taking precedence over enhancing teaching and learning activities. She continued, 'actually the university is turning away from its core focus [on teaching and learning]'.

The vice-chancellor at University S spoke frankly about the connections between the local context and the need to generate third-stream income. Speaking about the possibility of beginning new online degree programmes as a potential revenue source, he said 'And so in a context of Fees Must Fall your money and your ability to deploy cash is even more limited. In that context, how do you create the possibilities for technology enabled learning that works? And so, in that context you start looking for partners...'. The vice-chancellor believed that this could, if done the correct way, widen access to higher education through making courses more flexible and generate revenue for the institution's day-to-day functioning. The need to generate third-stream income was seen as particularly pressing; however, he spoke about the possibility of these income-generating activities subverting the research goals of staff and impacting on the institution's ranking:

[W]e are a research-intensive university and we need to retain sufficient time for academics to undertake research. If they start teaching at online and part-time and they don't do the research then we kind of, subvert our very strategic goal. So the question is, how do you not increase the burden? Or how do you increase the burden in a measured way?

In an ideal scenario, he argued the university would generate some profit and 'ring fence income and you redirect back into the academic projects'. In spite of the vice-chancellor's perception that he was not running a business, a senior academic leader spoke about 'the managerial practices are creeping in, so for example here there's performance management coming in and we get told, "[University A] does it so why can't you do it?"'. There was a tension in this context between the vision of the university as a place for knowledge production, which was not run as a 'business', and what was considered the reality of the university needing to be competitive to a global market. The core function of the university, in the eyes of some interviewees, was shifting away from teaching and learning functions, towards promoting the university through research and attempts to generate third-stream 
income. Our interviewees did not present the increasing focus on the market as a choice, although there were varying levels of critique of marketization. In various ways, all articulated a paradox: in order for teaching, research, and community engagement to survive, more income needs to be generated; yet, in order to generate more income, the university needs to shift its focus - at least partially - from teaching, research, and community engagement towards income generation.

While the marketisation of the university has been a feature in many postcolonial contexts, especially with the development of a more significant private for-profit sector of higher education in countries outside of European metropoles (see for example Mamdani 2007), the current marketisation discourses are a response to different kinds of conflicts. The shifts towards a more managerial university occurred with the cut of block grants to universities and the pressure on universities to compete with each for external research funding in order to improve their visibility or brand and attract more fee paying students in time of waning government support for higher education. As universities pursue rankings and visibility, they need to prioritise research. However, in the face of decreased government funding, there is increased pressure placed on institutions to provide for larger classes whose fees can subsidise the university's research-active staff members. Yet, with growing student numbers, the latter are also under pressure to perform more administrative and teaching tasks at the expense of research. Ultimately, these aims are coming into conflict with one another, as universities are pressed into serving these conflicting functions simultaneously.

\section{Rankings and reputation}

South African universities are not immune to global changes in higher education, and many have sought to rise in global ranking systems in order to enhance the prestige of their institutions and attract top quality researchers and local and international students. In the context of limited state funding, some South African universities are approaching the world ranking systems with optimism in the hopes that improved rankings will lead to increased income. Although questions of ranking were not key to the research focus of this project, our interviews at historically advantaged institutions indicated that rankings and reputation were key concerns of those in leadership positions. However, our interviewees were close to unanimous that ranking systems were flawed, and did not fully take into account the complexities of South African contexts and institutions.

At University S, the mission statement reflects the drive to be recognised as a world-leading research-intensive university, 'firmly embedded among international top league universities by 2022' (mentioning the Russell Group universities, the Australian Group of Eight and the top 5 in South Africa) (University S 2010, mission statement). The vice-chancellor of this university articulated the twin principles of social justice and international competitiveness that underline the university's mission. The institution should, in his view, 'be contextually grounded' but open to knowledge from throughout the world. He went on,

If you want marketing language you need to be contextually relevant and globally competitive. And people say to me, well that's market speak, it's not actually, frankly if you want to be a seriously global lead competitive place you need it to be contextually relevant, because ironically your context gives you your uniqueness and your 
uniqueness gives you something that you can contribute to the world that is different from everybody else and that's what makes you valuable to the global academy.

Rootedness in Africa was seen as potentially profitable, literally and symbolically. This vice-chancellor was critical of global ranking systems - referring to the process of rankings as generating 'propaganda'-while acknowledging their importance in terms of the global status of the university. Some academics at the institution were concerned about this strategy's effects on their students, saying that the competition between local universities for rankings was impacting on how staff valued their own teaching practices. Thus, the need to be recognised as a 'world leader' was constructed by some staff members as at odds with the teaching and learning functions of the university.

At University C, a large comprehensive university, an interviewee spoke about ambitions of 'our fearless leaders' to climb the global rankings, something that could only be done, in his view, through 'a very strong kind of managerial leadership'. He saw rankings as central to the future of the institution: 'universities chase ranking because everything flows from ranking. Everything'. The strategic objectives of this university include making research and innovation a central part of the university's mission and promoting effective teaching practices. It also hoped to achieve increased participation from international staff and students, and of upwardly mobile black students. However, perceived tensions between these multiple roles of the university were acknowledged by this respondent:

You know it's very difficult because we're chasing - we're chasing all the research indicators too. I mean, if you look at the three or four major ranking systems, we are acutely aware of how they comprise the criteria and add up their scores and we chase those scores, actively.... So we're doing lots of things at once. I don't think it's mutually exclusive, that you're either a kind of access institution or you're a prominent institution in the rankings, which often has a strong research implication. Our aim is to be a teaching university and a research university.

He was clear that the university did not want to be known as a teaching university — or as he put it - 'a farm for undergraduates'-which would pass all of the best students to other universities for their postgraduate degrees. In many interviews, there was an understood dichotomy between the elite, ranked, research-intensive institutions, who were able to maintain their position through attracting excellent academics and privileged students, and 'access institutions' that were actively seeking to broaden access to a larger cohort of students. Here, the imperatives for 'chasing' rankings were coming up against the need to be a strong, accessible teaching institution.

While these universities are seeking to develop their status as internationally ranked, research-intensive universities following the Anglo-American model, the picture at a historically disadvantaged university, University B, is quite different. As Lynch (2015) points out, ranking systems can 'exacerbate the stratification of universities' (2015: p. 197). HDIs have been severely affected by waning government subsidies, and their enrolments have decreased with students preferring to enter HAIs with more visible global reputations. Lack of government funding has been most closely felt by historically black institutions, where grants towards improving the infrastructure and 'efficiency' of institutions have failed to adequately address pre-existing inequalities (Badat 2015: p. 76). University B's vice-chancellor was clear that the university was not seeking to compete with other universities globally, let alone with HAIs 
locally: 'you're comparing apples and oranges, which can never be compared to anyone. They might taste the same, they might taste sweet, but they're not the same.' This vice-chancellor believed that the most important function of HDIs was to change the lives of individual students so that 'they can, beyond their degree, they can go and compete at, at, at [University A] if they so wish.'

It is worth noting that the discussions of the role of different kinds of universities within an integrated system can be traced to the size and shape discourse of the early 2000s. In this highly criticised policy recommendation (see Fataar 2003: p. 37), the Council on Higher education proposed a tiered system of universities, in which some would focus on undergraduate teaching, others on undergraduate teaching and limited postgraduate qualifications, and others on offering undergraduate and extensive postgraduate taught and research degrees (Council on Higher Education 2000). Some universities and technikons merged into new institutions known as universities of technology; others were termed comprehensive universities, and others research-intensive institutions. The aim behind this was to create a 'differentiated and diverse system so that there can be effective responses from institutions to the varied social needs of the country' (Council on Higher Education 2000: p. 8). However, as the Council on Higher Education wrote in 2016, the policies were unable to redress societal inequalities and the historical legacies of a differentiated system of higher education under apartheid (Council on Higher Education 2016: p. 41). Our respondents thus spoke in the context of a highly differentiated system in which the ability to attain a global ranking was not attainable across the sector. The interplay of this policy background with the increasingly influential system of global rankings thus affected universities in the sector differently, with advantaged, elite universities hoping to use the ranking system to bolster their reputation and disadvantaged institutions seeing these systems as beyond their reach.

Rankings were also a source of discussion for policymakers at the government level. One policymaker spoke about universities in South Africa seeking to bolster their reputations through global ranking systems, which she believed to be at odds with their role in preparing students for the workforce. The interviewee commented on the 'perversities' of the system, saying the criteria were not always relevant to the needs of the local context and economy. The Department of Higher Education and Training wanted to 'work with institutions to ensure that they don't become obsessed with their ranking at the expense of other aspects of their development'.

Another policy advisor spoke about the need for the government to be clearer on their stance regarding the growth of an international-facing higher education sector. 'Look, the government's never explicitly said, "We will bat for X number of universities who are going to be globally competitive." They duck that question. And sooner or later they're going to have to be a bit more explicit in that if - if we are to remain globally competitive...'. Here, the advisor argued that the government was neglecting its responsibility regarding the system as a whole. Implicit in the argument was a sense that the universities across the sector were not all going to become equal and that there were some that were more competitive globally. However, she argued that the government should do more to promote these top tier universities.

While many of our interviewees were critical of ranking systems, they emerged as a concern in the everyday life of some of the institutions under discussion. When rankings came up in our interviews, they were subject to some contestation, as the examples indicate. The pursuit of rankings was seen as at odds with a focus on students and teaching and learning activities and, sometimes, with the drive for widening access to higher education. At the same time that those at universities are beginning to see income-generating functions as either enhancing or encroaching 
on their 'core business', they are increasingly being pressed to provide a range of support to students that could serve the purpose of social redress. Speaking in the context of widespread protests and questions regarding the accessibility of institutions for poor and black students, interviewees reflected on social redress and accessibility as core functions of the university as well, often articulating these roles in relation to broader global missions.

\section{Historical inequalities, social justice, and access in marketising universities}

In South Africa, as in other postcolonial contexts, universities have been positioned as institutions of reparation with calls for reform including free higher education, decolonizing of curriculum and institutions (Leibowitz 2017), involvement of students in decision-making, and universities' financial and administrative autonomy from the state. There is considerable debate in South Africa about how to understand and respond to the current wave of student protests, particularly regarding calls for free higher education (Allais 2018; Motala et al. 2018). Indeed, the role of universities in addressing inequalities as part of their 'core business' arose in interviews in relation to societal redress and addressing inequality, both through improving the position of individual students and contributing to contextually grounded teaching and knowledge production. Although the student protests were not the focus of the research, almost all interviewees reflected on how protests had called into question the purpose and relevance of institutions as they are currently constituted.

At University A, a retired dean and policy advisor to the national government spoke about the university being seen as 'the route out of poverty' by many people. This reflection came as he considered the ways in which the broader higher education system was failing poor students, whose throughput was particularly slow and who still have the highest chances of not completing their degrees at all. He argued that universities should do more to serve those students who were entering the system, rather than catering for an imagined cohort of students, better prepared for higher education. Another interviewee at this institution agreed that the university should have a stronger emphasis on reflecting the community it was located within and foster a 'sense of belonging' for all students. While the imperatives around ranking, teaching, and research came up in the course of the discussion, the interviewee concluded by saying that the biggest challenge to the institution currently was that it was an environment 'entrenched in whiteness'. At this institution, where protesters have called attention to colonial symbols on the campus, the need to address the institution's past and present context is becoming increasingly pressing. This institution's mission statement positions the university within the African continent, the 'global south' and globally: 'Our qualifications are locally applicable and internationally acclaimed, underpinned by values of engaged citizenship and social justice' (University A Vision and Mission 2016). The quests for rankings and global recognition are situated alongside the need to provide a locally grounded education to students. However, the mission statement does not reflect the conflicts that many respondents felt between these different functions of the institution.

Tensions between teaching, research, and social justice imperatives, as well as the need to be financially viable and globally relevant, were felt at other institutions as well. At University $\mathrm{M}$, a large distance education institution, a senior leader reflected on the tensions in the role of the university, in light of recent student protests. For him, the context of the student protests had shifted responsibility for social redress to the higher education sector: 'often the social issues are now brought into the higher education space but - which in actual fact should not be but because nobody 
else is taking care of the social issues, it now sort of becomes our problem...' In fact, at this institution, protests had raised new demands from students, for things that the university had traditionally not provided: access to computer labs, work space on campus, and electronic devices. Apart from providing these services themselves, this also required cleaning and security services to be increased and 'all of this starts to snowball and, and where do you draw the line?' Here, the tension between the need to save money in light of lack of funding and the need to be responsive to students' demands was clear. This interviewee clearly called attention to what, from their perspective, should constitute the key focus of the institution — was the university's role to address these societal issues head-on or to provide undergraduate teaching for only those who can afford rising fees? Although social issues and responsiveness have long been central to the mandate of universities in South Africa, the interviewee perceived societal inequalities as an arena in which universities were increasingly compelled to intervene. While the policy context of the 1990s and 2000s clearly positioned higher education as a means of addressing societal inequality, interviewees often saw this as more urgent in the context of student protests that highlighted extreme inequalities in access to higher education.

At University $\mathrm{C}$, an interview with a senior leader revealed concern regarding student protests, and what an adequate response to protesters' demands might look like. When asked what the biggest challenge for the institution was, the leader answered that it was lack of funding in the context of the \#FeesMustFall protests. He said that the university was struggling due to lack of funding, but was also catering to a student population that was frequently hungry. 'So the biggest problem, for me, is students not eating...'. However, this university was seeking alternative revenue streams to widen access: in light of waning government subsidies, this interviewee said that providing online educational offerings might help the university to generate income to address this problem. 'So if you get online right, even while giving it lots and lots of resources, you can make a lot of money out of it or rather you can make money that you can then divert to other things to increase your global aspirations'. This university was attempting to provide wider access at the same time as addressing the lack of government funding, through commercially successful online programmes.

In the case above, marketisation was being proposed as a solution to a problem of inequality. If the university was able to generate more income, it could solve some of the issues of accessibility to the institution, although the exact mechanisms through which this would happen were not made clear. At University S, too, the possibility of creating more online education offerings was seen as a potential solution to issues of access at the university. One interviewee spoke of the twin imperatives of financial sustainability and widening access, saying that at the institution, 'we see ourselves as a big role player in equalising society. So we would look at whatever ways they are to, to, to equalise, and the technological platform is offering that.'

In cases like these where the universities were increasingly seeking external sources of funding in order to keep their teaching and learning activities going, they framed these initiatives as ways of addressing persistent inequalities in society. In this way, the two imperatives of generating income and equalising society were framed as part of 'core business', essential roles for a public university to play.

\section{Conclusion}

In one of our interviews, a retired member of senior management from University A expressed his frustration about the use of the concept of 'core business' in his institution today: 
What is core business? I cannot tell you how many senior meetings I've been in where somebody rushes in late and says, "Sorry, guys, you know, it's - I was held up by core business." That wasn't fixing the first year physics labs, you can be sure of that.

The idea of what should constitute the 'core business' of the institution, and indeed the very concept of 'core business' itself, is not ideologically neutral. South African universities' decisionmakers are juggling multiple objectives, which are not just contradictory in their logic, but also have quite divergent effects and impacts on the public higher education system. Do they pursue rankings and emphasise their research agendas, thus bringing in increased research funding? Do they turn to other options, including partnering with external organisations or marketising various aspects of provision in order to generate additional income? What are the implications for the role of public universities if they pursue all these options? The central dilemma is how to continue providing education that is globally competitive, while meeting the ever-widening plethora of needs of students, staff, and the broader community in a highly stratified society. Overall, there is a significant amount of weight put onto the university as an institution performing a key role in society. The ways that interviewees reflected on the 'core business' of universities shed light on tensions between the policy context, demands of students, and the needs of researchers. From a policy point of view, the primary role of universities is to prepare students for the workforce and to produce knowledge. For students, particularly those involved with protests, the role of the university is to provide redress both through access to the institution, funding, and student support and through teaching a relevant curriculum. For researchers, time and resources to conduct research are central to their own career progression and to being part of a global academic community. They also want to provide quality teaching and address social issues, although this is often not rewarded by the institution. As senior leaders, our interviewees positioned themselves at the crux of these competing demands.

In a country where higher education is commonly understood to be a pathway out of poverty, and a means of addressing historical injustices, universities are finding themselves forced to go into the market bringing into their 'core business' choices regarding that which is profitable. This is in addition to increasingly seeking third-stream income in the form of donations, research funding, online education provision through partnerships with private companies, and grants in order to keep their academic activities afloat. Thus, increasingly, South African higher education leaders are making changes to their understandings of 'core business'. Although teaching, research, and community engagement remain central to universities' understanding of their role in society, there is an increasing push for income generation to become part of the university's central function. While this income generation is, in some cases, positioned as a way to enhance teaching and learning facilities and offerings, in others, it is seen as a distraction from these foci and as interfering with the primary mission of public universities as centres of knowledge production and social redistribution.

Our interviews with senior leaders indicated that there have, at some institutions, been attempts to generate revenue through property holdings, attracting international students, and engaging with partners in order to provide online courses. Some leaders emphasised that these activities should be used only to support the key mission of the institutions, that is, teaching and research. However, others were concerned that the drives towards income generation were resource heavy, and given the austere budgets, would actually detract from researchers' time and ability to conduct work, and might have negative impacts on universities. In the case of rankings, some elite institutions saw global ranking systems as a way to bolster their reputations, attract foreign students, and increase third-stream income. However, many interviewees were concerned that the pursuit of rankings was detracting from the 'core business' of 
teaching and learning at universities and that these systems were not locally relevant. The context of austerity, increasing fees, and student protests regarding access - literal and symbolic - to institutions has made the mandate of serving a central role in South African society more urgent at some institutions. The need to provide locally relevant knowledge and curricula in courses with fees that are attainable to a larger number of students has come up against the need to compete internationally and to generate profits to keep universities open.

This study shows that in cases like South Africa, higher education is not simply moving into new terrain but is left in a precarious position, between a rock and a hard place: either it continues to be unequal, maintaining or increasing student fees, thus remaining socially stratified; or it increases participation in the market to gain revenue in order to buffer the immediate crisis, despite the realisation that elsewhere marketisation has invoked acute crises in the sector, even in societies less unequal than South Africa. This paper has revealed a new frontier at the interface of the public and private at public universities, showing how the very question of a 'core business' of a 'public university' is extremely problematic, possibly even an oxymoron. Where public universities have been understood as institutions for the public good, the notion of the university being involved in 'business' presents a major challenge to its public function. All of these issues remain contentious and subject to debate.

Open Access This article is distributed under the terms of the Creative Commons Attribution 4.0 International License (http:/creativecommons.org/licenses/by/4.0/), which permits unrestricted use, distribution, and reproduction in any medium, provided you give appropriate credit to the original author(s) and the source, provide a link to the Creative Commons license, and indicate if changes were made.

\section{References}

Allais, S. (2018). Analysis must rise: a political economy of falling fees. In D. Pillay, G. Khadiagala, R. Southall, \& S. Mosoetsa (Eds.), New South African Review 6. Johannesburg: Wits University Press.

Badat, S. (2015). Deciphering the meanings, and explaining the South African higher education student protests of 2015-16. Pax Academica, 1\&2, 71-106 http://paxacademica.codesria.org.

Ball, S. (2009). Privatising education, privatising education policy, privatising educational research: network governance and the 'competition state'. Journal of Education Policy, 24(1), 83-99. https://doi.org/10.1080 /02680930802419474.

Ballim, Y., Scott, I., Simpson, G., \& Webbstock, G. (2016). Regulation' in South African higher education reviewed: two decades of democracy (pp. 63-104). Pretoria: Council on Higher Education.

Bertelsen, E. (1998). The real transformation: the marketisation of higher education. Social Dynamics, 24, 130158.

Boden, R., \& Nedeva, M. (2010). Employing discourse: universities and graduate 'employability. Journal of Education Policy, 25, 37-54.

Bozalek, V., \& Boughey, C. (2012). (Mis)framing higher education in South Africa. Social Policy \& Administration, 46, 688-703.

Bradmore, D., \& Smyrnios, K. (2009). The writing on the wall: responses of Australian public universities to competition in global higher education. Higher Education Research \& Development, 28, 495-508.

Bunting, I. (2004). Students. In N. Cloete, P. Maassen, R. Fehnel, T. Moja, T. Gibbon, \& H. Perold (Eds.), Transformation in higher education: global pressures and local realities (2nd ed., pp. 95-111). Netherlands: Kluwer Academic Publishers.

Cloete, N. (2016). University fees in South Africa: a story from evidence. CHET May 2016. Accessed from https://chet.org.za/resources/sustainable-higher-education-funding-and-fees-south-africa. Last accessed 16 January 2017.

Collini, S. (2017). Speaking of universities. New York: Verso.

Council on Higher Education. (2014). Vital stats: public higher education 2014. Pretoria: Council on Higher Education. 
Council on Higher Education. (2016). South African higher education reviewed: two decades of democracy. Pretoria: Council on Higher Education.

Council on Higher Education. (2000). Towards a new higher education institutional landscape: meeting the equity, quality and social development imperatives of the twenty first century. (Report of the Size and Shape Task Team). Pretoria: Council on Higher Education.

Davis, R. (2017). Newsflash: President Zuma announces free higher education for poor students. Daily Maverick, 16 December 2017. Accessed at https://www.dailymaverick.co.za/article/2017-12-16ancdecides2017-newsflash-president-zuma-announces-free-higher-education-for-poor-students/\#. WmBJZFT1XeQ. Last accessed 4 February 2018.

Fataar, A. (2003). Higher education policy discourse in South Africa: A struggle for alignment with macro development policy. South African Journal of Higher Education, 17, 31-39.

Fehnel, R. (2004). Private higher education. In N. Cloete, P. Maassen, R. Fehnel, T. Moja, T. Gibbon, \& H. Perold (Eds.), Transformation in higher education: global pressures and local realities (2nd ed., pp. 227244). Netherlands: Kluwer Academic Publishers.

Giroux, H. A. (2014). Neoliberalism's war on higher education. Chicago: Haymarket Books.

Gumport, P. J., Iannozzi, M., Shaman, S., \& Zemsky, R. (1997). Trends in higher education from massification to post-massification. Stanford: National Center for Postsecondary Improvement.

Holmwood, J. (2014). From social rights to the market: neoliberalism and the knowledge economy. International Journal of Lifelong Education, 33, 62-76.

Howells, J., Jacks, S., Ramlogan, R., \& Cheng, S. (2012). Universities in an open innovation system: a UK perspective. International Journal of Entrepreneurial Behavior \& Research, 18, 440-456.

Ivancheva, M. (2013). The Bolivarian University of Venezuela: a radical alternative in the global field of higher education? Learning and Teaching, 6, 3-25.

Jansen, J. (2017). As by fire: the end of the South African university. Cape Town: Tafelberg.

Jessop, B. (2005). Critical realism and the strategic relational approach. New Formations, 56, 40-53.

Komljenovic, J., \& Robertson, S. L. (2016). The dynamics of 'market-making' in higher education. Journal of Education Policy, 31, 622-636.

Langa, M. (Ed.) (2017). \#Hashtag: an analysis of the \#FeesMustFall Movement at South African universities. Johannesburg: Centre for Violence and Reconcilation.

Leibowitz, B. (2017). Cognitive justice and the higher education curriculum. Journal of Education, 68, 93-112.

Lynch, K. (2010). Carelessness: a hidden doxa of higher education. Arts and Humanities in Higher Education, 9 , 54-67.

Lynch, K. (2014). New managerialism, neoliberalism and ranking. Ethics in Science and Environmental Politics, $13,141-153$.

Lynch, K. (2015). Control by numbers: new managerialism and ranking in higher education. Critical Studies in Education, 56, 190-207.

Lynch, K., \& Ivancheva, M. (2015). Academic freedom and the commercialisation of universities: a critical ethical analysis. Ethics in Science and Environmental Politics, 15, 71-85.

Mamdani, M. (2007). Scholars in the marketplace: the dilemmas of neo-liberal reform at Makerere University, 1989-2005. Dakar: CODESRIA.

Marais, H. (2001). South Africa: limits to change; the political economy of transition (2nd ed.). London: Zed Books.

Marginson, S. (2008). Global field and global imagining: Bourdieu and worldwide higher education. British Journal of Sociology of Education, 29, 303-315.

Marginson, S. (2016a). Public/private in higher education: a synthesis of economic and political approaches. Studies in Higher Education, 1-16.

Marginson, S. (2016b). Higher education and the common good. Melbourne: Melbourne University Publishing.

Motala, E., Vally, S., \& Maharajh, R. (2018). Education, the state and class inequality: the case for free higher education in South Africa. In D. Pillay, G. Khadiagala, R. Southall, \& S. Mosoetsa (Eds.), New South African review 6. Johannesburg: Wits University Press.

Ntshoe, I. M. (2004). Higher education and training policy and practice in South Africa: impacts of global privatisation, quasi-marketisation and new managerialism. International Journal of Educational Development, 24, 137-154.

Odhiambo, G. O. (2014). Quality assurance for public higher education: context, strategies and challenges in Kenya. Higher Education Research \& Development, 33, 978-991.

Ordorika Sacristán, I. (2003). Power and politics in university governance: organization and change at the Universidad Nacional Autónoma de México, studies in higher education, dissertation series. New York: Routledge Falmer.

Polanyi, K. (2001). The great transformation: the political and economic origins of our time. Boston: Beacon Press. 
Readings, B. (1999). The University in Ruins. Cambridge: Harvard Univ. Press.

Robertson, S. L. (2010). Corporatisation, competitiveness, commercialisation: new logics in the globalising of UK higher education. Globalisation, Societies and Education, 8, 191-203.

Sam, C., \& van der Sijde, P. (2014). Understanding the concept of the entrepreneurial university from the perspective of higher education models. Higher Education, 68, 891-908.

Shore, C. \& Wright, S. (2016). Neoliberalisation and the "Death of the Public University". Associazione Nazionale Universitaria Antropologi Culturali (ANUAC). https://doi.org/10.7340/anuac2239-625X-2451.

Simkins, C., Scott, I., Stumpf, R., \& Webbstock, D. (2016). Funding. In South African higher education reviewed: two decades of democracy (pp. 321-382). Pretoria: Council on Higher Education.

Slaughter, S. A., \& Leslie, L. L. (1997). Academic capitalism: politics, policies, and the entrepreneurial university. Baltimore, Md. London: Johns Hopkins University Press.

Treasury South Africa (1996). Growth, employment and redistribution: a macroeconomic strategy http://www. treasury.gov.za/publications/other/gear/all.pdf

Van der Berg, S. (2016) Funding university studies: who benefits? Kagisano, 10 (Student Funding) (173-86).

Washburn, J. (2008). University, Inc.: the corporate corruption of higher education. New York: Basic Books.

World Bank. (2018). Gini coefficients. https://data.worldbank.org/indicator/SI.POV.GINI?locations=ZA. Last accessed 9 January 2018.

Wysocki, B. (1999). Corporate America struggles to define 'core' business, Wall Street Journal, n.p. Accessed from http://www.wright.edu/ tdung/core.htm, 30 Jan 2018. 